\title{
PERAN PENGADILAN NEGERI INDONESIA DALAM PENYELESAIAN SENGKETA TRANSAKSI ELEKTRONIK INTERNASIONAL
}

\author{
Isdiyana Kusuma Ayu \\ Fakultas Hukum Universitas Islam Malang \\ Jalan MT Haryono Nomor 193 Malang \\ E-mail : isdiyana@unisma.ac.id
}

\begin{abstract}
Electronic transactions or E-commerce are buying and selling transactions carried out through the internet. As a result of over the internet, the nature of e-commerce can be done without knowing the borders. When a default or fraud occurs in e-commerce conducted by one of the parties who are abroad, it must pay attention to the principle of International Private Law related to the Court forum, Arbitration, or other dispute resolution institutions. That means that it is necessary to pay attention to the basic arrangements for dispute resolution of international business transactions that have been regulated in Indonesia and the authority of the Indonesian District Court in resolving international electronic transaction disputes. In the juridical perspective as the basis for solving electronic transaction cases to be legal strengthening takes a sense of justice so that it can be seen that the basis of international e-commerce arrangements in accordance with Article 18 Paragraph (4) of the ITE Law. District Courts has a role to be the main and complementary institution in dispute resolution international electronic transactions.
\end{abstract}

Keywords: Roles, Disputes, Electronic Transactions

\begin{abstract}
Abstrak
Transaksi Elektronik atau E-commerce merupakan transaksi jual beli yang dilakukan lewat internet. Akibat melalui internet, sifat e-commerce dapat dilakukan tanpa mengenal batas negara. Ketika wanprestasi atau adanya penipuan terjadi dalam e-commerce yang dilakukan oleh salah satu pihak yang berada di luar negeri maka harus memperhatikan asas Hukum Perdata Internasional terkait forum Pengadilan, Arbitrase, atau lembaga penyelesaian sengketa lainnya. Itu berarti perlu menjadi perhatian terhadap dasar pengaturan penyelesaian sengketa transaksi bisnis Internasional yang sudah diatur di Indonesia dan kewenangan Pengadilan Negeri Indonesia dalam menyelesaikan sengketa transaksi elektronik Internasional. Di dalam perspektif yuridis sebagai dasar penyelesaian kasus transaksi elektronik menjadi penguatan hukum mengambil rasa keadilan sehingga dapat diketahui bahwa dasar pengaturan e-commerce Internasional sesuai dengan Pasal 18 Ayat (4) UU ITE dan Pengadilan Negeri memiliki peran untuk menjadi lembaga utama dan pelengkap dalam penyelesaian sengketa transaksi elektronik internasional.
\end{abstract}

Kata Kunci: Peran, Sengketa, Transaksi Elektronik 


\section{A. PENDAHULUAN}

Transaksi elektronik atau sering disebut juga dengan e-commerce merupakan salah satu bentuk saluran penjualan yang potensial di Indonesia. E-commerce merupakan transaksi jual beli yang dilakukan lewat internet. Para pihak dalam transaksi elektronik tidak perlu bertatap muka langsung untuk melaksanakan transaksi perdagangan, dan dampak dari transaksi tanpa tatap muka langsung dengan melalui internet memudahkan perkembangan bentuk perdanganan tanpa batas sekaligus juga akan menimbulkan dampak hukumyang luas terhadap resiko yang ditimbulkan, ini dapat terjadi karena sifat e-commerce dapat dilakukan tanpa mengenal batas negara. Pelaksanaan e-commerce yang melewati batas negara harus mendapat perhatian lebih karena resiko yang ditimbulkan tidak mudah untuk diselesaikan.

Apabila terjadi suatu wanprestasi atau penipuan dalam e-commerce yang dilakukan dalam negeri akan mudah untuk diselesaikan dengan menggunakan lembaga penyelesaian sengketa yang ada di Indonesia, tetapi ketika wanprestasi atau adanya penipuan terjadi dalam e-commerce dilakukan oleh salah satu pihak yang berada di luar negeri maka harus memperhatikan asas hukum perdata Internasional terkait. Hal itu menjadi sangat penting karena harus mengetahui keterkaitan penegakkan hukum yang berhubungan dengan Lembaga forum Pengadilan, Arbitrase, atau lembaga penyelesaian sengketa lainnya yang ada dalam suatu wilayah hukum negara lain, ini sesuai sebagaimana terdapat pada Pasal 18 ayat 4 Undang-Undang Nomor 11 tahun 2008 tentang Informasi Teknologi dan Elektronik. Undang-Undang Nomor 11 tahun 2008 tentnag Informasi Teknologi dan Elektronik telah mengalami perubahan pada tahun 2016 yaitu Undang-Undang Nomor 19 Tahun 2016. Namun berkaitan dengan penyelesaian sengketa ini Pasal yang digunakan tidak mengalami perubahan yaitu Pasal 18 ayat 4.

Salah satu cara menyelesaikan sengketa e-commerce dapat dilakukan melalui forum pengadilan dalam hal ini Pengadilan Negeri. Pengadilan Negeri di Indonesia memiliki kewenangan yang terbatas dalam menyelesaikan permasalahan yang terjadi di negara yang berbeda. Kewenangan Pengadilan Negeri Indonesia tentunya akan terkait dengan yurisdiksi suatu negara dalam menyelesaikan masalah e-commerce.

Pelaksanaan e-commerce yang melewati batas negara sesuai dengan ketentuan yang terdapat pada Pasal 18 ayat 4 UU ITE akan berhubungan dengan yurisdiksi negara tersebut, yaitu terkait kewenangan suatu negara untuk menegakkan hukum di wilayahnya. Sehingga ketika terjadi sengketa -commerce terdapat kendala yang dihadapi oleh penegak hukum suatu negara untuk menindak pihak yang bersalah yang berada di wilayah yurisdiksi negara lain. Yurisdiksi suatu negara dalam Hukum Perdata Internasional memiliki peran di masingmasing negara, sehingga setiap negara berhak akan ketentuan-ketentuan hukum nasionalnya terhadap suatu masalah salah satunya tentang e-commerce.

Salah satu permasalahan terkait e-commerce bahwa Kementerian Komunikasi dan Informatika mendapatkan laporan penipuan dari negara-negara lain yang dilakukan situs-situs dagang (e-commerce) di Indonesia. Kementerian Komunikasi dan Informatik mendapatkan 
laporan dari para duta besar negara lain bahwa banyak terjadi penipuan yang dilakukan oleh situs dengan domain Indonesia. ${ }^{1}$ Penyelesaian sengketa tersebut tidak dapat segera diselesaikan karena harus melihat forum pengadilan yang digunakan. Namun, ketika akan diselesaikan di Indonesia maka harus mengetahui kewenangan dari Pengadilan Negeri Indonesia dalam menyelesaikan masalah tersebut. Oleh karena itu, perlu adanya penelitian terkait upaya Pengadilan Negeri Indonesia menegakkan kewenangannya untuk menyelesaikan sengketa transaksi elektronik Internasional dalam wilayah yurisdiksi Indonesia

Berdasarkan permasalahan yang terjadi tersebut maka perlu diketahui, a) Bagaimana dasar pengaturan penyelesaian sengketa transaksi bisnis Internasional melalui Pengadilan Negeri di Indonesia; serta b) Bagaimana peran Pengadilan Negeri Indonesia dalam menyelesaikan sengketa transaksi elektronik Internasional dalam wilayah yurisdiksi Indonesia.

\section{B. PEMBAHASAN}

\section{Dasar Pengaturan Penyelesaian Sengketa Transaksi Bisnis Internasional melalui Pengadilan Negeri di Indonesia}

Negara Indonesia telah mengatur terkait transaksi elektronik dalam Bab V UndangUndang Nomor 11 Tahun 2008 tentang Informasi dan Transaksi Elektronik, selanjutnya disebut UU ITE. Berdasarkan pasal 17 UU ITE menyebutkan bahwa, penyelenggaraan transaksi elektronik dapat dilakukan dalam lingkup publik ataupun privat. Para pihak yang terkait harus memiliki itikad baik dalam pelaksanaan transaksi elektronik tersebut.

Menurut Dikdik, "Kehadiran internet dalam perdagangan elektronik telah mengubah pola konsumen lebih kritis dan selektif dalam memilih produk yang diinginkan. Segi positif dari e-commerce juga dialami oleh produsen karena terjadi pemotongan rantai distribusi yang mampu menghemat biaya dan waktu, serta produsen dapat menghimpun data konsumen secara elektronik. Namun, juga terdapat segi negatif dari e-commerce yaitu ketidakhadiran para pihak memperbesar kemungkinan terjadinya kekeliruan terhadap barang atau kesungguhan konsumen dalam membeli serta kemungkin terjadi jika pelayanan yang diberikan produsen tidak memuaskan.",2

Berdasarkan jenis-jenis $e$-commerce yang ada, maka penulis melakukan penekanan pada penelitian terhadap transaksi Bussiness to Consumer ( $B$ to $C$ ). Hal ini disebabkan posisi konsumen dalam $B$ to $C$ memiliki posisi tawar yang lebih rendah dibandingkan dengan produsen atau pelaku usaha. Lemahnya posisi konsumen dalam transaksi $B$ to $C$ karena produsen menginginkan keuntungan sebesar-besarnya dari transaksi tersebut,

Business to Consumer e-commerce memiliki permasalahan yang berbeda. Mekanisme untuk mendekati konsumen pada saat ini menggunakan bermacam-macam

\footnotetext{
1 Rista Rama Dhany, 22 Maret 2014, Situs Dagang Online Domain Dotcom Banyak Penipuan, http://finance.detik.com/read/2013/03/22/200449/2201623/4/situs-dagang-online-domain-dotcom-banyakpenipuan, diakses pada tanggal 20 Juni 2018

${ }^{2}$ Dikdik M. Arief Mansur dan Elisatris Gultom, Cyber Law Aspek Hukum Teknologi Informasi, Refika Aditama, Bandung, 2009, hal 145.
} 
pendekatan misalnya dengan menggunakan "Electronic shopping mall" atau menggunakan konsep 'Portal'. ${ }^{3}$ Akibat adanya mekanisme ini terkadang konsumen yang tidak memiliki pengetahuan terkait penjualan online dapat mengalami kerugian, akibat penipuan yang dilakukan oleh penjual. Hal ini menandakan bahwa kedudukan konsumen tersebut dalam perlindungan haknya secara hukum masih lemah.

Menurut Dikdik, "Kedudukan konsumen menjadi lemah dalam transaksi elektronik karena beberapa faktor yaitu ketidaktahuan konsumen pada mitra bisnisnya, kurang pahamnya konsumen pada mekanisme transaksi, kurang jelasnya informasi yang diberikan produsen mengenai produk yang ditawarkan, dan sebagainya." 4 Faktor-faktor ini menyebabkan konsumen memiliki kecenderungan untuk dirugikan oleh produsen. Sehingga konsumen harus memiliki sikap yang cermat dan teliti dalam melakukan transaksi dalam e-commerce. Selain itu, produsen sebagai pihak yang penjual juga harus mengikuti aturan-aturan yang ada tanpa harus merugikan orang lain.

Hak dan kewajiban penjual dan pembeli dalam hal ini produsen dengan konsumen telah diatur dalam KUHPerdata, sedangkan pada E-commerce merupakan sistem di era digital dimana bentuk jual beli berkembang dari konvensional menuju ruang maya (cyber) atau berinvasi ke ruang daring atau online, sehingga hak dan kewajiban penjual dan pembeli dalam e-commerce dengan jual beli konvensional dinilai sama dengan unsur - unsur tersebut dibawah ini, yaitu:

a. Hak dan Kewajiban Penjual

- Hak Penjual, yaitu hak reklame, hak atas pembayaran harga atas barang, hak untuk menyatakan batal demi hukum.

- Kewajiban Penjual, yaitu menjamin tidak cacat tersembunyi, menjamin kenikmatan, tentram, dan damai, dan menyerahkan barang kepada pembeli.

b. Hak dan Kewajiban Pembeli

- Hak Pembeli yaitu memperoleh jaminan dari Penjual tidak adanya cacat tersembunyi dan hak untuk menunda pembayaran.

- Kewajiban Pembeli yaitu membayar harga, membayar bunga, dan melaksanakan pengambilan barang atas biaya sendiri.

Berdasarkan uraian hak dan kewajiban penjual dan pembeli, maka penjual dan pembeli dalam e-commerce harus mengetahui dan mengerti hak dan kewajiban masing-masing pihak agar tidak ada pihak yang dirugikan. Pengaturan hak dan kewajiban telah diatur secara jelas dalam KUH Perdata khususnya dalam Pasal 1457 KUH Perdata.

\footnotetext{
${ }^{3}$ Dewi Irmawati, Pemanfaatan E-Commerce dalam Dunia Bisnis, Jurnal Ilmiah Orasi Bisnis, Edisi ke-VI, November 2011, hal 100.

${ }^{4}$ Ibid, hal 146.
} 
Menurut Went Almovarid Dungga, "Transaksi e-commerce memiliki sedikit perbedaan dengan jual beli secara konvensional yaitu hanya terkait kerahasiaan data dan perlindungan data, perlindungan konsumen, tanggung jawab, kontrak perdata, hak atas kekayaan intelektual, tanda pengenal elektronik, retensi dan pemusnahan, dan sebagainya." 5 Selain itu, tidak ada perbedaan antara transaksi elektronik dengan transaksi konvensional sehingga hak dan kewajiban penjual atau pembeli sudah terdapat dan diatur dalam KUH Perdata.

Apabila hak dan kewajiban salah satu pihak tidak terpenuhi maka akan terjadi kerugian yang disebabkan oleh salah satu pihak kepada pihak yang lain. Selain itu berdasarkan pasal 18 Ayat 1 UU ITE yang menyebutkan bahwa transaksi elektronik yang dituangkan dalam kontrak elektronik mengikat para pihak. Kontrak on line dalam e-commerce menurut Santiago Cavanillas dan A. Martines Nadal, seperti yang dikutip oleh Arsyad Sanusi terdiri dari kontrak melalui chatting atau video conference, kontrak melalui email, dan kontrak melalui web atau situs. ${ }^{6}$ Bentuk kontrak dalam e-commerce berbentuk elektronik dan tidak dibuat diatas kertas.

E-commerce merupakan transaksi yang dilakukan di dunia maya bukan dunia nyata. Sehingga terdapat pandangan yang berpendapat bahwa hukum yang diberlakukan di dunia nyata tidak dapat diberlakukan di dunia maya. Hal ini sesuai dengan pendapat Karim Benyekhlef yang menyebutkan bahwa seseorang yang melakukan transaksi di dunia nyata dengan dunia maya memiliki perbedaan. Orang hanya memahami dunia maya sebatas unsurunsur yang bersifat teknik saja bukan terkait masalah-masalah hukum yang ditimbulkan akibat dari transaksi dunia maya. Meski, kenyataan bahwa internet bukan dimiliki oleh pemilik tunggal menguatkan pendapat Karim Benyekhlef tersebut. ${ }^{7}$ Namun, pendapat tersebut tidak dapat diterima karena perbuatan-perbuatan hukum yang dilakukan di dunia maya sebenarnya perbuatan-perbuatan yang dilakukan didunia nyata yang hanya berbeda pelaksanaan transaksi pada bentuk ruang dan media yang digunakannya saja.

Sehingga ketika para pihak telah melanggar perjanjian yang telah dibuat dan disepakatinya berarti telah melakukan suatu perbuatan yang melanggar aturan hukum perdata. Apabila pelanggaran ketentuan hukum perdata maka perbuatan tersebut termasuk perbuatan melawan hukum atau wanprestasi, maka setiap subyek hukum harus mematuhinya. Apabila tidak memenuhi hak atau kewajiban sebagai pihak tersebut maka telah melanggar pengaturan dalam KUH Perdata sehingga dapat digugat dalam Pengadilan. ${ }^{8}$

Perbuatan melawan hukum (PMH) atau wanprestasi dapat dilakukan oleh Produsen maupun Konsumen dalam e-commerce. Penyebab terjadinya PMH atau wanprestasi tersebut

\footnotetext{
${ }^{5}$ Weny Almovarid Dungga, Eksistensi Hukum dalam Pemanfaatan Teknologi Transaksi E-commerce, Jurnal Aplikasi Manajemen, volume 7, Nomor 2, Mei 2009, hal 385.

${ }^{6}$ Dian Wirdasari, Teknologi E-Commerce dalam Proses Bisnis, Jurnal Saintikom, volume 7 Nomor 2, Agustus 2009, hal 331.

7 Sutan Remy Sjahdeini, E-commerce Tinjuan Dari Perspektif Hukum, Jurnal Hukum Bisnis, volume 12, 2001, hal 2.

${ }^{8}$ Resa Raditio, Aspek Hukum Transaksi Eletronik Perikatan, Pembuktian, dan Penyelesaian Sengketa, Graha Ilmu, Yogyakarta, hal 30.
} 
karena salah satu pihak baik penjual maupun konsumen tidak memenuhi salah satu hak dan kewajibannya yang telah diatur dalam KUHperdata. Akibat adanya perbuatan melawan hukum PMH atau wanprestasi tersebut menimbulkan sengketa yang dapat diselesaikan dengan jalur litigasi yaitu Pengadilan atau non litigasi seperti Arbritrase. Sehingga pengaturan perbuatan melawan hukum PMH dan wanprestasi tidak hanya berlaku terhadap transaksi konvensional melainkan juga transaksi yang dilakukan melalui internet seperti e-commerce.

Fungsi penyelesaian sengketa dalam e-commerce yaitu agar norma-norma hukum yang mengatur hubungan dalam masyarakat dipatuhi. E-commerce yang merupakan transaksi elektronik yang dapat melintasi batas negara juga akan timbul sengketa apabila salah satu pihak tidak memenuhi hak dan kewajibannya. Apabila sengketa yang terjadi antara dua pihak yang berbeda negara maka harus melihat perjanjian yang telah dibuatnya terkait forum penyelesaian sengketa yang dipilihnya. Hal ini sesuai dengan Pasal 18 ayat (4) UU ITE yang menyebutkan bahwa "Para pihak memiliki kewenangan untuk menetapkan forum pengadilan, arbitrase, atau lembaga penyelesaian sengketa alternatif lainnya yang berwenang menangani sengketa yang mungkin timbul dari Transaksi Elektronik internasional yang dibuatnya."

Berdasarkan pasal 18 ayat (4) UU ITE maka dapat diketahui bahwa Pengadilan memiliki kewenangan untuk menyelesaikan sengketa transaksi elektronik. Pengadilan yang ditunjuk yaitu Pengadilan Negeri yang memiliki tugas dan wewenang untuk memeriksa, memutus, dan menyelesaikan perkara pidan dan perdata di tingkat pertama berdasarkan Pasal 50 Undang-Undang Nomor 2 Tahun 1986 tentang Peradilan Umum yang mengalami perubahan menjadi Undang-Undang Nomor 49 Tahun 2009. Apabila dikaitkan dengan transaksi internasional, maka Pengadilan Negeri berwenang untuk menyelesaikannya karena masih berkaitan dengan perkara perdata khususnya berkaitan dengan perjanjian antara kedua belah pihak yaitu penjual dan pembeli yang dilakukan secara online.

\section{Peran Pengadilan Negeri Indonesia Dalam Menyelesaikan Sengketa Transaksi Elektronik Internasional Dalam Wilayah Yurisdiksi Indonesia}

Permasalahan yang terjadi dalam transaksi $B$ to $C$ timbul karena tidak terpenuhi hak dan kewajiban salah satu pihak baik berupa perbuatan melawan hukum atau wanprestasi yang sudah dijelaskan sebelumnya. Penyelesaian sengketa tersebut tidak hanya terjadi dalam transaksi $B$ to $C$ yang terjadi dalam negeri saja melainkan juga bisa terjadi antara para pihak yang berbeda negara. Ketika sengketa tersebut terjadi antara para pihak dalam negeri akan mudah diselesaikan. Namun, ketika sengketa sudah menyangkut dua negara yang berbeda maka harus memperhatikan yurisdiksi pengadilan suatu negara dalam menyelesaikan masalah tersebut.

E-commerce internasional merupakan salah satu bentuk perdagangan internasional. Menurut Huala Adolf, hukum perdagangan internasional telah menentukan prinsip-prinsip mengenai penyelesaian sengketa perdagangan internasional yaitu: ${ }^{9}$

\footnotetext{
${ }^{9}$ Huala Adolf, Hukum Perdagangan Internasional, Rajawali Pers, Jakarta, 2011, hal 196.
} 

a. Prinsip kesepakatan para pihak.
b. Prinsipi Kebebasan memilih cara-cara penyelesaian sengketa
c. Prinsip kebebasan memilih hukum
d. Prinsip itikad baik
e. Prinsip Exhaustion of Local Remedies.

Prinsip-prinsip penyelesaian sengketa perdagangan internasional tersebut sebenarnya sudah dapat terselesaikan apabila kedua belah pihak menentukan diawal perjanjian mereka. Selain itu dapat terlihat bahwa hukum perdagangan internasional telah memberikan kebebasan terhadap para pihak dalam menyelesaikan sengketanya. Namun, ketika membahas perdagangan yang melintasi batas suatu negara, hal tersebut langsung berhubungan dengan yurisdiksi negara tersebut, yaitu mengenai kewenangan suatu negara untuk menegakkan hukum diwilayahnya. ${ }^{10}$

Menurut Assafa Endeshaw, masih belum ada negara yang berani untuk menunjukkan yurisdiksi dalam dunia maya dalam bentuk terpisah dan berbeda karena persoalan yurisdiksi dalam penyelesaian masalah e-commerce masih menimbulkan masalah lain. ${ }^{11} \mathrm{Hal}$ ini disebabkan bahwa lokasi dan waktu pelaksanaan e-commerce Internasional tersebut sulit ditentukan jika kontrak elektronik tidak mengatur forum penyelesaian sengketa dan kontrak tersebut tidak dapat dibuktikan. Menurut Edmon, "E-commerce merupakan transaksi perdagangan yang menggunakan internet maka teori yurisdiksi yang menekankan pada locus dan tempus delicti sudah tidak dapat digunakan lagi." 12

Yurisdiksi dalam UU ITE yaitu UU ITE berlaku untuk setiap orang yang melakukan perbuatan hukum berdasarkan UU ITE baik yang berada di dalam wilayah hukum Indonesia maupun di luar wilayah hukum Indonesia, yang memiliki akibat hukum di wilayah Indonesia dan/atau di luar wilayah hukum Indonesia dan merugikan kepentingan Indonesia yang tidak hanya meliputi kerugian yang ditimbulkan terhadap kepentingan ekonomi nasional, perlindungan data strategis, harkat martabat bangsa, pertahanan dan keamanan negara, kedaulatan negara, warga negara, dan badan hukum Indonesia. Jangkauan yurisdiksi dalam UU ITE tidak hanya untuk perbuatan hukum yang berlaku di Indonesia dan/atau dilakukan oleh WNI, tetapi juga berlaku untuk perbuatan hukum yang dilakukan di luar wilayah hukum Indonesia baik WNI maupun WNA.

Berdasarkan uraian tersebut dapat diketahui bahwa UU ITE tidak hanya berlaku di Indonesia melainkan juga diluar wilayah hukum Indonesia. Selain itu, pemberlakuan UU ITE juga tidak hanya kepada Warga Negara Indonesia melainkan juga Warga Negara Asing.

\footnotetext{
${ }^{10}$ Ayu Putriyanti, Yurisdiksi di Internet/Cyberspace, Media Hukum, Volume IX Nomor 2, April-Juni, 2009, hal 1 .

11 Assafa Endeshaw, Hukum E-commerce dan Internet dengan Fokus di Asia Pasifik, Pustaka Pelajar, Yogyakarta, 2007, hal 474.

${ }^{12}$ Edmon Makarim, Kompilasi Hukum Telematika, Raja Grafindo Persada, Jakarta, 2003, hal. 304.
} 
Pemberlakuan yang sangat luas ini disebabkan penggunaan Teknologi Informasi berupa internet dapat bersifat universal.

Menurut Purna Citra Nugraha, "Sejalan dengan pemikiran bahwa cyberspace memerlukan pengaturan baik inter-masyarakat maupun antar masyarakat, mulai dari norma sampai kepada hukum (cyberlaw) dan apabila dikaitkan dengan kewenangan suatu negara dalam melakukan pengaturan, hal tersebut tentu saja berhubungan langsung dengan yurisdiksi negara tersebut, misalnya saja mengenai kewenangan suatu negara untuk menegakkan hukum di wilayahnya atau dalam hal ini ruang siber. ${ }^{13}$

Akibat sifat yurisdiksi dalam UU ITE yang bersifat universal maka kewenangan negara dalam melakukan pengaturan untuk menyelesaikan suatu sengketa akan berkaitan dengan yurisdiksi suatu negara dalam menegakkan hukum di wilayahnya dalam permasalahan internet. Pada permasalahan e-commerce seharusnya dicarikan jalan keluar dari akibat-akibat yang muncul salah satunya terkait dengan yurisdiksi. Namun, dalam penyelesaiannya dapat membandingkan dengan negara lain dalam menyelesaikan masalah yang sama.

The principle issues of jurisdiction are which country's laws toengaged when disputes occur between business and consumer in more than one country, and the question over which court is able to judge the dispute. At first, this might appear only to be of importance to legal advocates, but there is an actual increase of cross-border ecommerce between consumers in one country buying goods or services from businesses based in other countries. Without certainty over the legal disputes and risks in this business to the consumer e-market, cross border e-commerce cannot reach its potential. ${ }^{14}$

Secara singkat uraian yang disampaikan Ong Chin Eang menyatakan bahwa masalahmasalah prinsip yurisdiksi hukum suatu negara pada awalnya hanya menjadi masalah kalangan advokat saja. Namun dengan adanya e-commerce menjadikan konsumen tidak hanya bertransaksi dalam negeri saja melainkan dapat melampaui batas lintas negara. Akibatnya tidak dapat memberikan kepastian hukum atas penyelesaian sengketa dan resikonya ecommerce tidak dapat mencapai potensinya.

Hal ini menandakan bahwa e-commerce masih memiliki kelemahan khususnya dalam hal penyelesaian sengketa yang terjadi di dua negara yang berbeda dalam masalah yurisdiksinya. Hal ini disebabkan juga kontrak antara kedua belah pihak tidak menentukan forum penyelesaian sengketa ketika dalam pelaksanaan kontrak tersebut timbul sengketa. Namun, permasalahan lainnya ketika ditentukan forum penyelesaian sengketa tersebut ternyata putusan hakim suatu negara juga belum tentu dapat dilaksanakan karena berkaitan dengan keberlakuan putusan hakim tersebut.

\footnotetext{
${ }^{13}$ Purna Cita Nugraha, Konsepsi Kedaulatan Negara Dalam Borderless Space, Jurnal Opinio Juris, Volume 13, Mei-Agustus 2013, hal 27.

${ }^{14}$ Ong Chin Eang, Jurisdiction in B2C E-commerce Redress, Idea Group Publishing, 2004, hal 1.
} 
Pernyataan dari Ong Chin Eang juga diperkuat dengan pendapat yang disampaikan Faye Fangfe Wang dalam artikelnya yang menyebutkan bahwa"However, there is still no clear indication of the creation of a special regime of jurisdiction rules for e-commerce cases. It is a process, which is time and money consuming. Even if efforts were made to draft a specific regulation or convention, it would still take time and efforts to come into force."

Secara singkat dapat diketahui bahwa Faye Fangfe Wang juga menjelaskan bahwa masih belum ada indikasi yang jelas terkait aturan khusus yang mengatur yurisdiksi yang menyelesaikan kasus-kasus e-commerce. Apabila terjadi permasalahan dalam e-commerce maka akan membuang waktu dan uang dari para pihak yang bermasalah. Sehingga pembuatan konvensi atau regulasi masih membutuhkan waktu dan upaya untuk keberlakuannya. Sehingga dapat diketahui bahwa permasalahan e-commerce bila terjadi sengketa akan sulit diselesaikan karena masih belum adanya aturan internasional yang mampu memberikan kejelasan dalam penyelesaiannya.

Menurut Rina Arum, "Dalam internet pelaku pelanggaran seringkali menjadi sulit dijerat karena hukum dan Pengadilan Indonesia tidak memiliki yurisdiksi terhadap pelaku dan perbuatan hukum yang terjadi, mengingat pelanggaran hukum bersifat transnasional tetapi akibatnya justru memiliki implikasi hukum di Indonesia." ${ }^{16}$ Namun, permasalahan yang terjadi dalam e-commerce harus tetap diselesaikan agar memperoleh keadilan dan kepastian hukum.

Pasal 18 ayat (4) UU ITE menyebutkan bahwa penyelesaian sengketa $e$-commerce dapat diselesaikan dengan forum pengadilan, arbitrase, atau penyelesaian sengketa alternatif lainnya. Pemilihan forum tersebut berdasarkan kewenangan yang diberikan kepada para pihak untuk memilih. Namun, ketika tidak ada ketentuan maka akan diselesaikan dengan menggunakan asas hukum perdata internasional.

Namun, ketika tidak ditentukannya forum penyelesaian sengketa akan membawa masalah baru. Permasalahan tersebut terkait penerapan hukum yang akan digunakan. Penerapan tersebut berdasarkan hukum negara tergugat atau berdasarkan hukum negara penggugat atau berdasarkan negara pelaku usaha atau dari pembeli. ${ }^{17}$ Berdasarkan Penjelasan Pasal 18 ayat (5) UU ITE menyatakan bahwa apabila para pihak tidak melakukan pilihan forum, maka kewenangan yang berlaku berdasarkan prinsip hukum perdata internasional yaitu asas tempat tinggal tergugat (the basis of presence) dan efektivitas yang menekankan pada tempat harta benda tergugat berada (principle of effectiveness).

Asas lain dalam Hukum Perdata Internasional yang berkaitan dengan transaksi elektronik secara internasional yaitu lex loci solutions, lex loci executions. Asas ini memiliki

\footnotetext{
${ }^{15}$ Faye Fangfei Wang, Obstacles and Solutions to Internet Jurisdiction A Comparative Analysis of the EU and US Laws, Journal of International Commercial Law and Technology, Volume 3, Issue 4, 2008, hal 240.

${ }^{16}$ Rina Arum Prastyanti, Evaluasi Efektivitas Undang-Undang No. 11 Tahun 2008 tentang Informasi dan Transaksi Elektronik dalam Pelaksanaan E-Commerce, Duta.Com, Volume 5 Nomor 1, 2013, hal 26.

${ }^{17}$ Abdul Halim Barkatullah, Penerapan Aribtrase Online dalam Penyelesaian Sengketa Transaksi E-commerce, Jurnal Hukum, Nomor 3 Volume 17, Juli, 2010, hal. 303.
} 
arti bahwa tempat dilaksanakannya perjanjian merupakan titik tali pertalian sekunder pula. ${ }^{18}$ Berdasarkan asas tersebut, sepanjang perjanjian itu dilakukan di Indonesia maka hukum Indonesia dapat digunakan untuk menyelesaikan sengketa transaksi elektronik internasional, khususnya yang akan diselesaikan oleh Pengadilan Negeri di Indonesia dan perjanjian yang tidak menentukan forum hukum.

Penyelesaian sengketa e-commerce yang merupakan persoalan yang berkaitan dengan dunia bisnis berpotensi menginginkan penyelesasian dengan cepat, efektif, adil, biaya murah, dan tidak menyita waktu banyak. Penyelesaian sengketa dalam e-commerce dapat diselesaikan dengan beberapa bentuk mekanisme yaitu melalui:

a. Proses Ajudikasi, yang meliputi peradilan dan arbitrase

b. Proses Konsensus, yang meliputi Negosiasi, Mediasi, dan Konsiliasi.

Berdasarkan dua mekanisme tersebut maka dimungkinkan menggunakan mekanisme penyelesaian sengketa alternatif berupa Arbitrase. Hal ini mengingat proses yang ditawarkan oleh Arbitrase mampu memberikan penyelesaian yang cepat dan adil. Apabila menggunakan lembaga peradilan terdapat beberapa kekurangan yaitu penyelesaian sengketa lambat, biaya perkara yang mahal karena penyelesaian perkara yang lama, peradilan yang tidak tanggap, putusan pengadilan tidak menyelesaikan masalah, kemampuan para hakim bersifat generalis.

Kekurangan lembaga peradilan dalam menyelesaikan masalah tersebut maka diperlukannya lembaga penyelesaian alternatif yaitu Arbitrase yang memiliki keuntungan berupa waktu yang cepat, biaya yang sesuai dengan waktu yang diberikan, keahlian pihak yang menyelenggarakan arbitrase, dan mekanisme penyelesaian sengketa yang dirahasiakan. ${ }^{19}$ Meskipun pengadilan tidak dipercaya dalam hal penyelesaian sengketa e-commerce. Keberadaan Pengadilan Negeri masih diperlukan sebelum, saat, dan setelah proses Aribtrase berlangsung. ${ }^{20}$

a. Sebelum proses Arbitrase berlangsung

Pengadilan memiliki peran dalam menentukan pengadilan mana yang berwenang untuk menyelesaikan sengketa tersebut, pengadilan mengakui kekuatan mengikat dari klausul arbitrase dalam perjanjian yang dibuat para pihak, berperan dalam penunjukan arbiter apabila arbiter kedua tidak dapat menunjuk arbiter ketiga, pemberian jangka waktu khususnya terhadap permasalahan yang hanya berkaitan dengan kedua belah pihak.

b. Saat proses Arbitrase berlangsung

Para pihak dalam jangka waktu 30 hari sejak diterimanya ketentuan arbitrase dapat meminta kepada pengadilan untuk menentukan keputusan mahkamah arbitrase

\footnotetext{
${ }^{18}$ Sudargo Gautama, Hukum Perdata Internasional, PT. Eresco Bandung, 1986, hal. 54.

${ }^{19}$ Dikdik M Arief Mansur, Op.cit, hal 176.

${ }^{20}$ Gunawan Widjaja dan Michael Adrian, Seri Aspek Hukum dalam Bisnis Peran Pengadilan dalam Penyelesaian Sengketa oleh Arbitrase, Kencana Prenada Media Group, Jakarta, 2008, hal 6.
} 
mana yang tidak boleh diajukan keberatan, pengadilan memiliki kewenangan untuk mengambil barang bukti yang diperlukan selama proses arbitrase dengan persetujuan majelis arbitrase dan para pihak.

c. Setelah proses arbitrase berlangsung

Pengadilan dapat mengesampingkan putusan arbitrase dengan syarat salah satu pihak dapat membuktikan bahwa perjanjian arbitrase tidak sah dan bertentangan dengan hukum negara yang bersangkutan, salah satu pihak tidak berikan pemberitahuan penunjukan arbiter, putusan arbitrase yang dijatuhkan berasal dari suatu sengketa yang tidak dapat diselesaikan dengan arbitrase, dan putusan arbitrase bertentangan dengan ketertiban umum negara yang bersangkutan.

Meskipun Pengadilan tidak dijadikan upaya pertama dalam menyelesaikan masalah $e$ commerce namun kewenangan Pengadilan Negeri juga selalu ada dalam proses Arbitrase. Selain itu, Pengadilan juga berperan dalam pelaksanaan putusan arbitrase dalam hal eksekusi. ${ }^{21}$ Akan tetapi peran Pengadilan Negeri tidak dapat dikesampingkan begitu saja, pengadilan negeri biasanya ditempuh apabila cara-cara dalam penyelesaian sengkata yang ada ternyata tidak berhasil. Penyelenggaraan penyelesaian sengketa di Pengadilan Negeri hanya dimungkinkan ketika para pihak menentukannya dalam perjanjiannya. ${ }^{22}$

Pengadilan Negeri juga berwenang dalam menyelesaikan sengketa e-commerce yang ditujukan pada lembaga tersebut. Penyelesaiannya juga harus sesuai dengan kaidah-kaidah hukum Internasional karena tidak berada dalam satu wilayah hukum. Apabila dalam kontrak elektronik telah ditentukan terkait forum pengadilan mana yang berhak, pengadilan harus memeriksa dan tunduk dengan perjanjian tersebut. Namun, ketika tidak ada pilihan forum dalam perjanjian maka asas hukum perdata internasional yang digunakan sesuai dengan aturan dalam UU ITE. Asas hukum perdata internasional yang digunakan dalam penyelesaian sengketa yaitu asas tempat tinggal tergugat (the basis of presence), efektivitas yang menekankan pada tempat harta benda tergugat berada (principle of effectiveness), dan lex loci solutions, lex loci executions. Asas ini memiliki arti bahwa tempat dilaksanakannya perjanjian merupakan titik tali pertalian sekunder pula. ${ }^{23}$

Kelebihan dari UU ITE yaitu tidak hanya berlaku di Indonesia melainkan juga diluar wilayah hukum Indonesia. Selain itu, pemberlakuan UU ITE juga tidak hanya kepada Warga Negara Indonesia melainkan juga Warga Negara Asing. Pemberlakuan yang sangat luas ini disebabkan penggunaan Teknologi Informasi berupa internet dapat bersifat universal. Meskipun sifat UU ITE yang bersifaat universal terdapat masalah lain terkait pemberlakuan putusan pengadilan negeri dalam masalah e-commerce internasional.

Menurut Purna Cita Nugraha, "Kedaulatan, kewenangan, dan yurisdiksi suatu negara terhadap persoalan dunia maya belum mendapatkan posisi yang jelas sehingga menyebabkan

\footnotetext{
${ }^{21}$ Resa Raditio, Op.cit, hal 62.

${ }^{22}$ Huala Adolf, Op.cit, hal 212.

${ }^{23}$ Sudargo Gautama, Hukum Perdata Internasional, PT. Eresco Bandung, 1986, hal. 54.
} 
ketidakpastian dalam pelaksanaan prinsip extraterritorial jurisdiction terhadap pelanggaran dalam dunia maya termasuk e-commerce. Praktek negara-negara selama ini secara sepihak dalam memberlakukan hukum nasionalnya. Namun pemberlakuannya dikhawatirkan akan melahirkan kesewenang-wenangan suatu negara." 24

Pendapat tersebut memang menyebabkan permasalahan dalam penerapan putusan pengadilan Indonesia terhadap sengketa $e$-comerce. Meskipun Pengadilan Negeri berwenang memutuskan perkara e-commerce tetap saja tidak dapat secara langsung diberlakukan karena belum adanya posisi yang jelas terkait kewenangan dan kedaulatan. Sehingga sebagai Negara berdaulat sudah seharusnya menentukan kebijakan yang mampu mengantisipasi permasalahan hukum melalui politik hukum yang tepat dan dalam membentuk infrastruktur hukum khususnya terkait tentang e-commerce.

\section{PENUTUP}

Dasar pengaturan penyelesaian sengketa transaksi bisnis Internasional melalui Pengadilan Negeri di Indonesia yaitu diatur dalam Pasal 18 ayat 4 UU ITE. Pengadilan Negeri dapat menyelesaikan perkara transaksi elektronik internasional karena masih menjadi tugas dan wewenang Pengadilan Negeri untuk menyelesaikan perkara perdata.

Peran Pengadilan Negeri Indonesia dalam menyelesaikan sengketa transaksi elektronik Internasional dalam wilayah yurisdiksi Indonesia yaitu menjadi lembaga utama atau sebagai pelengkap. Sebagai lembaga utama, artinya Pengadilan Negeri menyelesaikan perkara transaksi elektronik internasional sejak awal perkara itu masuk. Sebagai lembaga pelengkap yaitu ketika Pengadilan Negeri tidak dipilih untuk menyelesaikan transaksi internasional tetapi berperan dalam arbritase yaitu dalam sebelum, sesaat, dan sesudah arbritrase berlangsung.

\section{DAFTAR PUSTAKA}

\section{Buku}

Assafa Endeshaw, Hukum E-commerce dan Internet dengan Fokus di Asia Pasifik, Pustaka Pelajar, Yogyakarta, 2007.

Dikdik M. Arief Mansur dan Elisatris Gultom, Cyber Law Aspek Hukum Teknologi Informasi, Refika Aditama, Bandung, 2009.

Edmon Makarim, Kompilasi Hukum Telematika, Raja Grafindo Persada, Jakarta, 2003.

Gunawan Widjaja dan Michael Adrian, Seri Aspek Hukum dalam Bisnis Peran Pengadilan dalam Penyelesaian Sengketa oleh Arbitrase, Kencana Prenada Media Group, Jakarta, 2008.

Huala Adolf, Hukum Perdagangan Internasional, Rajawali Pers, Jakarta, 2011.

Resa Raditio, Aspek Hukum Transaksi Eletronik Perikatan, Pembuktian, dan Penyelesaian Sengketa, Graha Ilmu, Yogyakarta, 2014.

Sudargo Gautama, Hukum Perdata Internasional, PT. Eresco Bandung, 1986

\footnotetext{
${ }^{24}$ Purna Cita Nugraha, Op.cit, hal 41
} 


\section{Jurnal}

Abdul Halim Barkatullah, Penerapan Aribtrase Online dalam Penyelesaian Sengketa Transaksi E-commerce, Jurnal Hukum, Nomor 3 Volume 17, Juli, 2010.

Ayu Putriyanti, Yurisdiksi di Internet/Cyberspace, Media Hukum, Volume IX Nomor 2, April-Juni.

Dewi Irmawati, Pemanfaatan E-Commerce dalam Dunia Bisnis, Jurnal Ilmiah Orasi Bisnis, Edisi ke-VI, November 2011.

Dian Wirdasari, Teknologi E-Commerce dalam Proses Bisnis, Jurnal Saintikom, volume 7 Nomor 2, Agustus 2009.

Faye Fangfei Wang, Obstacles and Solutions to Internet Jurisdiction A Comparative Analysis of the EU and US Laws, Journal of International Commercial Law and Technology, Volume 3, Issue 4, 2008.

Ong Chin Eang, Jurisdiction in B2C E-commerce Redress, Idea Group Publishing, 2004.

Purna Cita Nugraha, Konsepsi Kedaulatan Negara Dalam Borderless Space, Jurnal Opinio Juris, Volume 13, Mei-Agustus 2013.

Rina Arum Prastyanti, Evaluasi Efektivitas Undang-Undang No. 11 Tahun 2008 tentang Informasi dan Transaksi Elektronik dalam Pelaksanaan E-Commerce, Duta.Com, Volume 5 Nomor 1, 2013.

Sutan Remy Sjahdeini, E-commerce Tinjuan Dari Perspektif Hukum, Jurnal Hukum Bisnis, volume 12, 2001.

Weny Almovarid Dungga, Eksistensi Hukum dalam Pemanfaatan Teknologi Transaksi Ecommerce, Jurnal Aplikasi Manajemen, volume 7, Nomor 2, Mei 2009

\section{Undang-Undang}

Undang-Undang Nomor 49 Tahun 2009 tentang Perubahan Undang-Undang Nomor 2 Tahun 1986 tentang Peradilan Umum.

Undang-Undang Nomor 19 Tahun 2016 tentang Perubahan atas Undang-Undang Nomor 11 Tahun 2008 tentang Informasi dan Teknologi Elektronik.

\section{Internet}

Rista Rama Dhany, 22 Maret 2014, Situs Dagang Online Domain Dotcom Banyak Penipuan, http://finance.detik.com/read/2013/03//situs-dagang-online-domain-dotcom-banyakpenipuan, diakses pada tanggal 20 Juni 201 